\title{
PERAN ZAKAT TERHADAP PEMBERDAYAAN DAN KESEJAHTERAAN MUSTAHIQ
}

\author{
Akmalur Rijal \\ Universitas Islam Lamongan \\ e-mail: akmalurrijal@yahoo.com
}

\begin{abstract}
Poverty is a crucial problem that is being faced by all nations in the world, including Indonesia. This condition will certainly disrupt national development and stability. Therefore, what is needed now is a solution that can help overcome the problems. The poverty is defined as the inability of a person to fulfill his basic needs because of his powerlessness in accessing or mastering economic resources. The inequality of economic development is one of the causes of poverty. Welfare is a condition that is a hope for every citizen. But in reality not all citizens can easily get welfare. The empowerment of productive zakat funds has a very large role in the business mustahiq, because of the limitation to increase capital in its business, so that zakat funds become one of the solutions to advance business mustahiq. Productive zakat has the specificity of being channeled to the production business of mustah\}iq. Productive businesses carried out by mustahiq with capital from productive zakat. His efforts are expected to be able to continue to grow, so that being able to raise the economic level of mustahiq so that achieving prosperity can even become muzakki.
\end{abstract}

\section{Keywords: Zakat, Mustahiq, Zakat Empowerment}

\section{Pendahuluan}

Kemiskinan merupakan satu persoalan krusial yang tengah dihadapi seluruh bangsa di dunia tidak terkecuali Indonesia. Kondisi tersebut tentunya akan mengganggu pembangunan dan stabilitas nasional. Oleh karena itu, yang dibutuhkan saat ini adalah suatu solusi yang dapat membantu mengatasi permasalahan di atas. Kemiskinan didefinisikan sebagai ketidakmampuan seseorang dalam memenuhi kebutuhan dasarnya karena ketidakberdayaan dalam mengakses atau menguasai sumber-sumber ekonomi. Ketidakmerataan pembangunan ekonomi menjadi salah satu penyebab terjadinya kemiskinan. Kesejahteraan merupakan suatu kondisi yang menjadi harapan bagi setiap warga negara. Namun pada kenyataannya tidak semua warga negara dapat dengan mudah mendapatkan kesejahteraan. Berbicara tentang masalah kesejahteraan dalam Islam, tentunya hal tersebut tidak dapat dilepaskan dengan pembahasan mengenai zakat. Zakat sendiri merupakan bagian dari rukun Islam yang wajib dijalankan bagi setiap umat muslim. Jika dilihat dari manfaatnya, zakat merupakan suatu ibadah māliyyah yang menyangkut hubungan antara manusia dengan sesama manusia dan hubungan antara manusia denganAllah SWT.

Di dalam hubungan antara sesama manusia zakat memiliki fungsi saling menolong di mana seseorang yang memiliki kekayaan dapat menyisihkan sebagian hartanya untuk menolong orang lain yang sedang membutuhkan dengan ketentuan-ketentuan tertentu. Sedangkan di dalam hubungan antara manusia dengan Allah SWT, zakat merupakan suatu bentuk ibadah atau wujud ketaatan seorang hamba terhadap Tuhannya. 
Yusuf Qardhawi juga berpendapat bahwa zakat merupakan ibadah māliyyah ijtimā'iyyah yang memiliki posisi yang sangat penting, strategis dan menentukan, baik dari sisi ajaran maupun sisi pembangunan dan kesejahteraan umat apabila dilakukan secara optimal. Kelebihan dari zakat produktif akan berdampak positif secara nyata dalam menghilangkan kesenjangan hidup masyarakat yang sejahtera dan mampu hidup lebih baik lagi serta akan lebih mandiri, sehingga ia tidak akan menerima zakat karena telah mampu bangkit dari kemiskinan menuju kaya dan sejahtera. Zakat produktif ini sangat urgen dalam membangun masyarakat dan perekonomian bangsa yang sejahtera. Sesuai dengan fatwa MUI, dana zakat yang diberikan kepada fakir miskin dapat bersifat produktif.

Zakat sesungguhnya memiliki potensi yang besar dan memungkinkan apabila dijadikan sebagai solusi, sumber keuangan zakat tidak akan pernah habis ataupun berhenti, karena zakat merupakan panggilan agama sehingga setiap muslim akan senantiasa menunaikan kewajiban membayar zakat setiap tahun atau pada setiap periode yang ditetapkan.

Badan Amil Zakat (BAZ) dan Lembaga Amil Zakat (LAZ) sebagai institusi resmi pengelola zakat menyalurkan dana zakat kepada parapenerima zakat (mustahiq) khususnya fakir miskin melalui penyaluran zakat secara konsumtif untuk memenuhi keperluan konsumsi sehari-harinya maupun secara produktif untuk menambah modal usaha. Konsepsi program pemanfaatan zakat secara produktif mengasumsikan bahwa dengan dana zakat yang penerimanya tidak memiliki kewajiban untuk mengembalikan dana serta adanya pendampingan, usaha mikro para mustahiq yang menjadi target program bisa berjalan dan kesejahteraannya meningkat.

Pendayagunaan zakat harus memberikan dampak positif bagi mustahiq, baik dari segi ekonomi maupun sosial. Dari sisi ekonomi, mustahiq dituntut untuk dapat hidup layak dan mandiri, sedangkan dilihat dari sisi sosial, mustahiq dimotivasi untuk dapat hidup sejajar dengan masyarakat lainnya. Hal tersebut menunjukkan bahwa zakat tidak hanya bersifat suatu amalan yang didistribusikan untuk hal-hal konsumtif saja, namun juga untuk kepentingan mustahiq yang bersifat produktif dan kreatif.

Kekurangan modal bukan merupakan satu-satunya kelemahan golongan miskin dalam membangun usahanya, tetapi juga kemauan untuk maju, kesiapan mental, dan kesiapan manajemen usaha. Pada tahap awal pendistribusian zakat terutama zakat produktif, pihak 'ämil zakat memberikan pemberdayaan dalam bentuk pembinaan, yaitu mendidik dan mengarahkan mustahiq agar memiliki keinginan untuk maju dan berkembang, kemudian mendampingi mustahiq dalam menjalankan usahanya sehingga kegiatan usahanya tersebut dapat berjalan dengan baik dan agar para mustahiq semakin meningkatkan kualitas keimanan dan keislamannya. Peningkatan kualitas keimanan dan keislaman akan memberikan efek domino untuk memacu semangat agar terlepas dari jurang kemiskinan, sehingga mengobarkan semangat untuk berusaha dan meningkatkan kesejahteraannya.

Pemberdayaan dana zakat produktif memiliki peran yang sangat besar terhadap usaha mustahiq, karena keterbatasan untuk melakukan penambahan modal dalam usahanya, sehingga dana zakat menjadi salah satu solusi untuk memajukan usaha mustahiq selain adanya bantuan dari pemerintah maupun lembaga keuangan lainnya. Bantuan dana yang diberikan oleh pemerintah atau lembaga keuangan lainnya cenderung memiliki kewajiban untuk mengembalikan dana yang disalurkan tersebut, sedangkan dana zakat tidak ada 
kewajiban untuk mengembalikan kepada 'āmil. Kemudahan yang dimiliki oleh dana zakat harus dimanfaatkan sebesar-besarnya oleh amil atau lembaga penyalur zakat, agar berperan dalam pemberantasan kemiskinan dan peningkatan kesejahteraan umat. Berdasarkan latar belakang yang ada, maka dapat disusun rumusan masalah sebagai Bagaimana peran zakat untuk pemberdayaan dan kesejahteraan mustahiq?

\section{Zakat}

Ditinjau dari segi bahasa, kata zakat mempunyai beberapa arti, yaitu al-barakah 'keberkahan', al-namā 'pertumbuhan dan perkembangan', al-țahārah 'kesucian', dan al-ṣalāh 'keberesan'. Sedangkan secara istilah, meskipun para ulama mengemukakannya dengan redaksi yang sedikit berbeda antara satu dengan yang lainnya, akan tetapi pada prinsipnya sama, yaitu bahwa zakat itu adalah bagian dari harta dengan persyaratan tertentu yang Allah SWT wajibkan kepada pemiliknya, untuk diserahkan kepada yang berhak menerimanya, dengan persyaratan tertentu pula.

Hubungan antara pengertian zakat menurut bahasa dan dengan pengertian menurut istilah, sangat nyata dan erat sekali, yaitu bahwa harta yang dikeluarkan zakatnya akan menjadi berkah, tumbuh, berkembang dan bertambah, suci dan beres (baik). Hal ini sebagaimana dinyatakan dalam al-Quran:

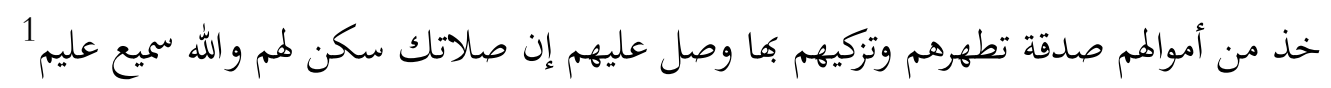

"Ambillah zakat dari sebagian harta mereka, dengan zakat itu kamu membersihkan dan menyucikan mereka, dan berdoalah untuk mereka. Sesungguhnya doa kamu itu menjadi ketentraman jiwa buat mereka. Dan Allah Maha Mendengar lagi Maha Mengetahui."

وما آتيتم من ربا ليربو في أموال الناس فلا يربو عند الله وما آتيتم من زكاة تريدون وجه الله فأولئك هم المضعفون2

"Dan sesuatu riba (tambahan) yang kamu berikan agar dia bertambah pada harta manusia, maka riba itu tidak menambah pada sisi Allah. Dan yang kamu berikan berupa zakat yang kamu maksudkan untuk mencapai keridhaan Allah, maka (yang berbuat demikian) itulah yang melipat gandakan hartanya."

Zakat adalah ibadah dalam bidang harta yang mengandung hikamh dan manfaat yang demikian besar dan mulia, baik yang berkaitan dengan orang yang berzakat (muzakki), penerimanya (mustahiq), harta yang dikeluarkan zakatnya, maupun bagi masyarakat keseluruhan.

Hikmah dan manfaat zakat yang mencakup dua dimensi, baik vertikal maupun horizontal, menjadikan zakat sebagai suatu mekanisme yang sangat potensial ketika itu dikembangkan. Zakat merupakan salah satu instrumen yang dapat dapat membawa hikmah dan manfaat kepada yang memberi dan juga menerima. Manfaat kepada pemberi zakat adalah

\footnotetext{
al-Quran, 9: 103.

2 al-Quran, 30: 39.
} 
aplikasi bentuk ibadah sehingga dinilai dengan pahala, sedangkan bagi penerima zakat sebagai bantuan yang bisa dimanfaatkan untuk meningkatkan kesejahteraan penerima zakat.

\section{Pendayagunaan Zakat}

Pendayagunaan zakat merupakan proses penyaluran zakat dalam rangka meningkakan manfaat (daya guna) instrumen zakat. Pendayagunaan tersebut bisa dilakukan pengelola zakat yang berasal dari pihak zakat lewat berbagai program pendayagunaan dan penyaluran zakat. Program tersebut bisa dalam rangka bersifat jangka pendek yang bersifat konsumtif atau dalam rangka program jangka panjang seperti program bersifat produktif termasuk di dalamnya program pemberdayaan. Ruang lingkup program pendayagunaan zakat terhadap kebutuhan dasar akan berdampak pada peningkatan konsumsi baik secara mikro ekonomi dan makro ekonomi. Secara makro ekonomi peningkatan konsumsi tersebut akan meningkatkan pendapatan secara nasional sebagaimana variabel konsumsi merupakan salah satu instrumen pendapatan nasional. Sedangkan di sisi lain secara konvensional peningkatan konsumsi akan diiringi dengan peningkatan investasi terutama dalam bidang-bidang kebutuhan dasar tersebut.

Peningkatan konsumsi akibat distribusi zakat terhadap berbagai program pemenuhan kebutuhan dasar cenderung bersifat periodik belaka. Sedangkan peningkatan investasi sebagai respon terhadap peningkatan pemintaan tersebut bersifat memiliki respon lebih lambat. Pada akhirnya peningkatan konsumsi tersebut hanya akan juga bersifat periodik pula pada pendapatan nasional, sebagaimana yang terjadi pada periode hari raya keagaman dimana selalu terdapat kecenderungan kenaikan konsumsi pada masa-masa tersebut. Pemenuhan kebutuhan dasar lewat zakat tersebut tentunya perlu direspon dengan berbagai berbagai skema pendistribusian berdampak pada jangka waktu yang lebih panjang dan jauh jangka waktunya terutama bagi golongan mustahiq.

Dampak zakat begitu luas dan memiliki dampak signifikan terhadap berbagai sektor sosial kemasyarakatan khususnya bidang ekonomi yang menyasar aspek kebutuhan masyarakat. Dampak tersebut selaras dengan berbagai makna zakat secara bahasa. Banyak athār dan hadist menjadi landasan pengelolaan zakat terhadap berbagai alokasi zakat kepada 8 golongan yang bersifat konsumtif dan produktif. Khusus dalam kaitannya dalam berbagai kegiatan produktif, bahwa sebagian dari golongan penerima zakat (mustahiq) yang antara lain seperti fakir, miskin, hamba sahaya, gharim (orang yang berutang) merupakan sebagaian mustahiq yang banyak lepas dari akses pemberdayaan sehingga zakat membantu menopang pemberdayaan.

Berbagai golongan tersebut merupakan golongan yang menjadi sasaran zakat dimana zakat diharapkan tidak hanya berdampak dalam jangka pendek belaka, namun dampaknya juga jangka panjang dengan berbagai kegiatan produktif. Jika dilakukan analisis secara mikro, tentunya berbagai program zakat secara produktif membantu meningkatkan pendapatan sebagian golongan penerima zakat tersebut. Selain itu dalam jangka panjang, tujuan zakat untuk golongan tersebut mampu mengangkat golongan tidak hanya sebagai golongan mustahiq bertransformasi menjadi golongan pemberi zakat (muzakki). Kegiatan produktif lewat instrumen zakat membuktikan bahwa dalam prinsip ekonomi islam melakukan kegiatan produktif merupakan hal yang dianjurkan pada setiap individu. Maka tidak heran kemudian 
zakat merupakan instrumen yang secara nyata mengangkat banyak pihak dari keterpurukan ekoonomi sehingga dalam jangka panjang akan mengurangi kemiskinan.

Program zakat produktif dan konsumtif diperlukan berjalan bersama dan beriringan. Program zakat secara produktif tidak serta merta berjalan secara sendiri sesuai dengan tujuan fungsinya terutama untuk golongan pihak fakir tidak bisa melakukan kegiatan secara produktif jika pihak fakir tersebut ada dalam keadaan lapar, tidak terdidik atau bahkan tidak memiliki keterampilan. Sedangkan zakat secara konsumtif juga tidak bisa juga dilakukan secara sendiri karena pada jangka panjang pemberian zakat secara konsumtif tidak disertai dengan berbagai kegiatan pemberdayaan dalam hal ini kegiatan produktif justru hanya akan memberikan ketergantungan pihak sasaran zakat tersebut. Senada apa yang diungkapkan oleh tokoh fiqih yang banyak dijadikan rujukan lewat berbagai karyanya, Yusuf Qordhowi:

"Semua yang telah dilakukan oleh orang Barat memiliki banyak kesulitan, namun dalam Islam pola pikir terhadap timbunan sangat jelas dan fleksibel dibandingkan dengan sistem-sistem lain. Zakat mempunyai aturan yang sangat jelas dan adil karena itu dalam sistem zakat diwajibkan bagi setiap orang untuk membayarkan 2,5 persen dari harta yang dimiliki setiap tahunnya. Hal ini mampu memberikan dorongan kepada para penerima zakat agar dapat memberdayakan uang dan harta yang mereka terima dengan baik sehingga peningkatan ekonomi yang diharapkan dapat tercapai" 3

Pada analsis secara makro, kedua program produktif dan konsumtif terhadap sasaran zakat sesuai syariah akan berdampak pada peningkatan pertumbuhan ekonomi secara signifikan dengan perlakuan secara masif regional ekonomi. Zakat yang disalurkan dalam aspek konsumtif saja, secara makro akan meningkatkan variabel konsumsi pada penghitungan pendapatan nasional yang merupakan indikasi yang baik dalam pendapatan nasional. Lewat zakat pula mekanisme pasar berjalan lebih merata, karena zakat menolong pihak-pihak yang termarginalkan tingkat konsumsinya dimana sebelumnya mekanisme pasar berlaku hanya pada pihak yang mampu. Selain itu secara bersamaan, zakat yang disalurkan lewat program produktif merupakan indikasi meningkatnya angka investasi sebagai alokasi kegiatan usaha sebuah regional.

Berdasarkan program zakat yang produktif tersebut, tentunya akan meningkatkan nilai variabel investasi pada pendapatan nasional. Ilustrasi sederhana tersebut merupakan dasar pertumbuhan ekonomi dalam sebuah negara bisa tumbuh secara signifikan dengan zakat. Maka tidak heran jika kemudian terdapat banyak pendapat yang mengungkapkan pembudayaan zakat sebagai variabel pendorong pertumbuhan ekonomi dan memacu perekonomian tetap berputar meski dalam masa resesi. Hal tersebut senada dengan apa yang telah diungkapkan Manan:

"Dengan adanya zakat atas harta timbunan dapat mengakibatkan pengaruh yang sangat signifikan pada beberapa sektor ekonomi, seperti daya produksi meningkat, mengurangi pengangguran, dan pengurang perbedaan pendapatan, dalam catatan tersebut tidak hanya habis dikonsumsi akan tetapi hasil penerimaan zakat benar-benar disalurkan dan

\footnotetext{
${ }^{3}$ Nurul Huda dkk, Zakat dalam Perspektif Mikro dan Makro Pendekatan Riset (Jakarta: Predana Media Grup, 2015), 137.
} 
diberdayakan melalui kegiatan-kegiatan ekonomi dan seterusnya yang kemudian dapat menghasilkan keuntungan". ${ }^{4}$

Oleh karena itu elemen zakat dengan berbagai dimensi hikmah dan fungsinya memiliki dampak implikasi terhadap kehidupan masyarakat baik terkait langsung maupun tidak. Selain itu pula bahwa skema berbagai program kelembagaan zakat membantu meningkatkan elemen modal sosial masyarakat dimana selama ini cenderung terabaikan.

\section{Pemberdayaan Mustahiq}

Konsep pemberdayaan saat ini mulai banyak berkembang dimana guna mendorong pembangunan masyarakat secara merata. Selain itu prinsip pemberdayaan selaras dengan konsep demokrasi yang saat ini berkembang di Indonesia. Masyarakat secara langsung memiliki andil secara mandiri terhadap kehidupannya sehingga berbagai akses kebutuhan dalam kehidupan dapat terakses oleh masyarakat secara merata.

Pemberdayaan merupakan salah satu cara yang penting saat ini sehingga bermuara pada pembangunan masyarakat secara utuh. Sebagai negara berkembang, Indonesia perlu melakukan pembangunan secara menyeluruh dan merata dengan terus menerus mengembangkan bentuk pemberdayaan masyarakat. Pemberdayaan yang dalam bentuk memperhatikan aspek sosial dan kemanusiaan lebih komprehensif sebagaimana kelembagaan yang menyandarkan aspek analisisnya lebih luas.

Pengelola zakat mendayagunakan zakat lewat program-program pemberdayaan mengarahkan masyarakat agar lebih berdaya dalam jangka panjang terhadap kehidupannya sendiri. Bentuk pendayagunaan zakat tersebut selaras dengan bagaimana konsep yang dikemukakan oleh Paul bahwa pemberdayaan berarti pembagian kekuasaan yang adil sehingga meningkatkan kesadaran politis dan kekuasaan pada kelompok yang lemah serta memperbesar pengaruh mereka terhadap proses dan hasil-hasil pembangunan."

Meski kemudian beragam pendapat dikemukakan para ahli, namun terdapat irisan konsep pemberdayaan berjalan yakni dimana pemberdayaan masyarakat merupakan upaya untuk memampukan dan memandirikan masyarakat. Atau dengan kata lain adalah bagaimana menolong masyarakat untuk mampu menolong dirinya sendiri. Selanjutnya perlu diidentifikasi beberapa ciri prinsip pemberdayaan sehingga berbagai bentuk program pemberdayaan bisa benar-benar mencapai tujuan pemberdayaan tersebut. Menurut Sumodiningrat, pemberdayaan memiliki tiga sisi utama sudut pandang: ${ }^{5}$

1. Menciptakan suasana atau iklim yang memungkinkan potensi masyarakat berkembang (enabling).

2. Memperkuat potensi atau daya yang dimiliki masyarakat (empowering).

3. Memberdayakan mengandung pula arti melindungi. Dalam proses pemberdayaan, harus dicegah yang lemah menjadi bertambah lemah, oleh karena kekurangberdayaan dalam menghadapi yang kuat.

\footnotetext{
${ }_{5}^{4}$ Ibid., 137-138.

5 Agus Purbathin Hadi, Konsep Pemberdayaan, Partisipasi dan Kelembagaan dalam Pembangunan (t.t: Yayasan Agrobisnis/Pusat Pengembangan Masyarakat Agrikarya, 2010), 178.
} 


\section{Peran Zakat}

Pendayagunaan zakat merupakan sebuah upaya dalam peningkatan kebermanfaatan zakat kepada para mustahiq. Kebermanfaatan instrumen zakat tersebut bisa saja dilakukan dengan beriringan dengan instrumen filantropi yang lain baik infaq dan shadaqah sekaligus. Upaya pendayagunaan Zakat yang diintegrasikan dengan instrumen filantropi Islam lainnya bisa dilakukan secara syariat dimana para așnăf zakat merupakan sasaran yang searah dengan infaq dan shadaqah. Bahkan dalam dalil aṣnăf zakat, bahwa kata yang digunakan diawali dengan kata shadaqah.

Upaya pendayagunaan zakat juga dipakai dalam perundang-undangan zakat di Indonesia dimana merupakan tugas pada 'āmil pengelola zakat baik berasal dari BAZNAS dan LAZNAS. Pada pelaksanaannya, pendayagunaan zakat banyak dicerminkan dengan berbagai program yang dilaksanakan BAZNAS dan LAZNAS. Program pemberdayaan dilakukan dalam rangka mendapatkan pendayagunaan zakat dalam jangka panjang dengan sifat suistainable. Program pemberdayaan merupakan salah satu solusi jangka panjang dari permasalahan kesejahteraan yang terjadi di masyarakat sebagaimana yang telah dilakukan BAZNAS dan LAZNAS di Indonesia.

\section{Pemberdayaan Mustahiq Melalui Zakat}

Zakat merupakan salah satu instrumen agung yang memiliki dampak besar bagi kehidupan dan kesejahteraan manusia. Zakat memegang peranan penting terutama dalam konteks kesejahteraan secara material dan bahkan non-material kehidupan manusia. Oleh karena itu sebenarnya zakat merupakan perintah dan menjadi dasar agama yang tidak perlu dipertanyakan lagi derajat kewajiban dalam agama hingga pada hikmah zakat. Selain itu islam yang diturunkan oleh Allah SWT merupakan Dzat yang Maha Mengetahui apa yang baik bagi ciptaan-Nya.

Zakat merupakan instrumen yang berperan dalam peningkatan kesejahteraan, tentunya perlu terus didorong dalam terwujudnya masyarakat yang sejahtera terutama mengingat keadaan masyarakat Indonesia yang masih banyak dalam keadaan pra-sejahtera. Oleh karena itu upaya pengelolaan zakat juga perlu didorong secara masif dalam peningkatan kesejahteraan masyarakat salah satunya dengan desentralisasi dalam pendayagunaan zakat. Keberadaan LAZ dalam pengelolaan zakat telah dirumuskan sebagaimana UU No. 23 Tahun 2011, yaitu dalam rangka membantu pengumpulan, pendistribusian dan pendayagunaan. Pendayagunaan zakat sendiri merupakan aspek penting jalan peningkatan daya manfaat bagi masyarakat dimana sebagai jalan menuju masyarakat yang lebih sejahtera. Pada realitanya meski sebagai pihak yang membantu tugas BAZNAS, LAZ juga memiliki peranan penting pada aspek pendayagunaan terutama peningkatan efektifitas dan efisiensi pengelolaan zakat sebagaimana tujuan pengelolaan zakat pada pasal 3 UU No 23 tahun 2011.

Pada aspek pendayagunaan urgensi pendayagunaan LAZ memiliki dasar sesuai dengan pasal 27 pada UU No. 23 Tahun 2011. Beragam metode dilakukan dalam rangka tujuan pendayagunaan yaitu dalam penanganan fakir miskin dan peningkatan kualitas umat sebagaimana pasal 27 UU No. 23 Tahun 2011 dan Peraturan Menteri Agama No. 52 Tahun 2014. Pada aspek tujuan dan metode, pendayagunaan zakat identik dengan model-model pemberdayaan masyarakat yang sasarannya selaras dengan mustahiq zakat. 
Konsep pendayagunaan zakat dengan bentuk pemberdayaan masyarakat dilakukan dalam rangka mengatasi permasalahan kemiskinan sesuai dengan pasal 27 UU No. 23 Tahun 2011. Amanah UU tersebut mengindikasikan bahwa peranan ideal kelembagaan zakat dan bentuk filantropi Islam diarahkan kepada pengentasan permasalahan kemasyarakatan. Peranan LAZ tersebut bukan semata-mata berdasarkan amanah UU belaka, melainkan karakteristik sasaran filantropi Islam tersebut menyasar kepada pihak-pihak yang merupakan bagian dari permasalahan sosial kemasyarakatan. Oleh karena itu perkembangan pengelolaan zakat dalam kelembagaan zakat telah selaras dengan semangat penyelesaian permasalahan sosial kemasayarakatan di Indonesia sebagai negara berkembang.

Penerapan zakat dalam berbagai bentuk program telah mampu menyelesaikan permasalahan sosial kemasyarakatan. Berbagai penelitian seperti beberapa di antaranya diterbitkan lembaga-lembaga amil zakat skala nasional yang bekerja sama dengan pihak dan lembaga penelitian yang kapabel di antaranya Indonesia Zakat and Development Report yang diterbitkan secara berkala. Pada hasil publikasi penelitian tersebut terbukti dampak zakat lewat kajian empiris dengan sasaran golongan ashnaf zakat fakir dan miskin dapat menurunkan angka kemiskinan, tingkat kedalaman kemiskinan, di beberapa kota besar di Indonesia.

Penelitian mengenai dampak zakat terhadap kemiskinan juga dilakukan berbagai aktivis zakat dimana dampak zakat terhadap kesenjangan pendapatan yang dilakukan kelembagaan zakat. Seperti salah satunya pada penelitian yang dilakukan Irfan Syauqi dengan berbagai alat rasio dimana zakat dapat mengurangi jumlah angka kemisikinan, kedalaman kemiskinan hingga pada kesenjangan pendapatan. Penelitian tersebut membuktikan bahwa golongan fakir dan miskin bisa mendapatkan perubahan setelah mendapat distribusi zakat yang dilakukan dengan cara terstruktur. Selain itu pula peran kelembagaan zakat (ZIS) dimana relatif lebih terstruktur akan mampu diukur tingkat keberhasilannya. ${ }^{6}$

Zakat yang dilakukan dengan pendekatan lembaga relatif akan memberikan dampak secara terukur dan terdeskripsi dengan baik. Maka guna meningkatkan peranan ZIS, pihakpihak pengelola zakat termasuk pemerintah di dalamnya yang memiliki otoritas untuk mendorong pihak pengelola zakat untuk berbagai program pemberdayaan bagi masyarakat. Program-program pemberdayaan yang dilakukan guna meningkatkan pendayagunaan zakat bagi masyarakat sebagaimana pedoman-pedoman pengelolaan zakat dalam berbagai perangkat perundang-undangan.

Bentuk dan arah peningkatan pendayagunaan ZIS sendiri telah didorong oleh berbagai perangkat dan landasan undang-undang yang mengarahkan kepada dampak dalam jangka panjang. Oleh karena itu guna mendapatkan dampak dalam jangka panjang tersebut tidak dapat dipungkiri dipengaruhi pula oleh efektifitas dan efisiensi dalam pengelolaan ZIS. Arah dan bentuk pendayagunaan ZIS dalam jangka panjang diarahkan pada berbagai program pemberdayaan masyarakat yang sasarannya selaras dengan syariat ZIS. Namun berdasarkan sebagai pemilik otoritas tertinggi dalam pengelolaan zakat, pemerintah menetapkan standar pemberdayaan terutama terkait zakat. Salah satu bentuk pemberdayaan masyarakat dalam pendayagunaan zakat dengan bentuk usaha produktif. Pemerintah dalam Peraturan Menteri

\footnotetext{
${ }^{6}$ Irfan Syauqi Beik, "Analisis Peran Zakat dalam Mengurangi Kemiskinan: Studi Kasus Dompet Dhuafa Republika” dalam Zakat dan Empowering: Jurnal Pemikiran dan Gagasan, Vol. 11, Tahun 2009.
} 
Agama Nomor 52 Tahun 2014 pendayagunaan zakat dalam usaha produktif dapat dilakukan dalam kriteria sebagaimana dalam pasal 33:

1. Apabila kebutuhan dasar mustahik telah terpenuhi;

2. Memenuhi ketentuan syariah;

3. Menghasilkan nilai tambah ekonomi untuk mustahiq, dan

4. Mustahik berdomisili di wilayah kerja lembaga pengelola zakat"

Kriteria tersebut merupakan syarat dalam melakukan pemberdayaan dengan berdasarkan dana zakat untuk kegiatan usaha produktif. Namun secara umum usaha produktif merupakan salah satu bentuk program pemberdayaan selain dalam bentuk program lainnya. Menurut Sumodiningrat, pemberdayaan memiliki tiga sisi utama sudut pandang: ${ }^{7}$

1. Menciptakan suasana atau iklim yang memungkinkan potensi masyarakat berkembang (enabling).

2. Memperkuat potensi atau daya yang dimiliki masyarakat (empowering).

3. Memberdayakan mengandung pula arti melindungi. Dalam proses pemberdayaan, harus dicegah yang lemah menjadi bertambah lemah, oleh karena kekurangberdayaan dalam menghadapi yang kuat.

\section{Kesimpulan}

Berlandaskan rumusan masalah dan hasil pembahasan di atas, maka dapat diambil beberapa kesimpulan, yakni, bahwa dalam instrumen ekonomi Islam, terdapat instrument zakat yang bersifat jangka panjang, yaitu zakat produktif. Sedangkan tujuan dari zakat produktif adalah menjadikan mustahiq zakat menjadi muzakki dengan memberikan permodalan kepada mereka. Tidak cukup dengan pemberian modal, mereka juga harus didik dan dibina, sehingga zakat yang diberikan kepada mereka tidaklah bersifat konsumtif jangka pendek, melainkan produktif jangka panjang.

Zakat produktif berperan sangat besar untuk meningkatkan kesejateraan mustahiq. Zakat produktif memiliki kekhususan disalurkan untuk usaha produkstf dari mustahiq. Usaha produktif yang dilaksanakan oleh mustahiq yang bermodal dari zakat produktif. Usahanya diharapkan mampu untuk terus berkembang, sehingga mampu mengangkat taraf ekonomi mustahiq sehingga mencapai kesejahteraan bahkan bisa menjadi muzakki.

\section{Daftar Rujukan}

Andriati, Rizky. "Tidak Sekedar Menebar Uang” dalam Sharing. Edisi 76, Tahun VII, April 2013.

Al-Syafi'i, Syaikh Muhammad bin Abdul Rahman. Rohmatul Ummah fi Ikhtilafil A'imah, AlHaramain. t.t: t.p., t.th.

Al-Utsaimin, Syaikh Muhammad Shalih. Ensiklopedi Zakat: Kumpulan Fatwa Zakat. Jakarta: Pustaka as-Sunnah, 2008.

Beik, Irfan Syauqi. "Analisis Peran Zakat dalam Mengurangi Kemiskinan: Studi Kasus Dompet Dhuafa Republika" dalam Zakat dan Empowering: Jurnal Pemikiran dan Gagasan. Vol. 11, Tahun 2009.

Hadi, Agus Purbathin. Konsep Pemberdayaan, Partisipasi dan Kelembagaan dalam

\footnotetext{
${ }^{7}$ Agus Purbathin Hadi, Konsep Pemberdayaan, Partisipasi dan Kelembagaan, 162.
} 
Pembangunan. t.t: Yayasan Agrobisnis/Pusat Pengembangan Masyarakat Agrikarya, 2010.

Huda, Nurul dkk. Zakat dalam Perspektif Mikro dan Makro Pendekatan Riset. Jakarta:

Predanamedia Grup, 2015.

Hafidhuddin, Didin. Zakat, Infak \& Sedekah, Cetakan II. Jakarta: Baznas, 2006.

Miftah, A.A. "Pembaharuan Zakat untuk Pengentasan Kemiskinan di Indonesia" dalam Jurnal Innovation. Vol. VIII, No. 2, Juli-Desember 2009.

Muhammad, Qutb Ibrahim. Bagaimana Rasulullah Mengelola Ekonomi, Keuangan, dan Sistem Administrasi. Jakarta: Gaung Persada Press, 2007.

Sabri, Hisham bin dan Zulkifli bin Hasan. "Zakat: Instrumen Penyumbang Pembentukan Usahawan" dalam Seminar Kebangsaan Pengurusan Harta dalam Islam, Kolej Islam Pahang Sultan Ahmad Shah, Kuantan, 2006.

Sa'idah, Lailatus. "Studi Tentang Zakat Sebagai Kebijakan Instrumen Fiskal di Indonesia". Skripsi--UIN Sunan Kalijaga Yogyakarta, 2008.

Sartika, Mike. "Pengaruh Pendayagunaan Zakat Produktif terhadap Pemberdayaan Mustahiq pada LAZ Yayasan Solo Peduli Surakarta” dalam Jurnal Ekonomi Islam La_Riba. Vol. II, No. 1, Juli 2008.

Winoto, Garry Nugraha. Pengaruh Dana Zakat Produktif Terhadap Keuntungan Usaha Mustahik Penerima Zakat (Studi Kasus BAZ Kota Semarang). Skripsi--Universitas Diponegoro Semarang, 2011. 